\title{
Current state and trends in Canadian Arctic marine ecosystems: I. Primary production
}

\author{
Jean-Éric Tremblay • Dominique Robert • \\ Diana E. Varela • Connie Lovejoy • Gérald Darnis • \\ R. John Nelson • Akash R. Sastri
}

Received: 10 February 2012 / Accepted: 6 May 2012

(C) The Author(s) 2012. This article is published with open access at Springerlink.com

\begin{abstract}
During the International Polar Year (IPY), large international research programs provided a unique opportunity for assessing the current state and trends in major components of arctic marine ecosystems at an exceptionally wide spatio-temporal scale: sampling covered most regions of the Canadian Arctic (IPY-Canada's Three Oceans project), and the coastal and offshore areas of the southeastern Beaufort Sea were monitored over almost a full year (IPY-Circumpolar Flaw Lead project). The general goal of these projects was to improve our understanding of how the response of arctic marine ecosystems to climate warming will alter the productivity and structure of the food web and the ecosystem services it provides to Northerners. The present paper summarizes and discusses six key findings related to primary production (PP), which determines the amount of food available to consumers. (1) Offshore, the warming and freshening of the surface layer is leading to the displacement of large nanophytoplankton species by small picophytoplankton cells, with potentially profound bottom-up effects within the marine food web. (2) In coastal areas, PP increases as favourable winds and the deeper seaward retreat of ice promote upwelling. (3) Multiple upwelling events repeatedly provide food to herbivores throughout the growth season. (4) A substantial amount of pelagic PP occurs under thinning ice and cannot be detected by orbiting sensors. (5) Early PP in the spring does not imply a trophic mismatch
\end{abstract}

J.-É. Tremblay $(\bowtie) \cdot$ D. Robert $\cdot$ C. Lovejoy $\cdot$ G. Darnis

Québec-Océan, Département de biologie, Université Laval, 1045 avenue de la Médecine, Québec, QC G1V 0A6, Canada

e-mail: jean-eric.tremblay@bio.ulaval.ca

D. E. Varela

Department of Biology \& School of Earth and Ocean Sciences, University of Victoria, P.O. Box 3020, Stn CSC, Victoria, BC V8W 3N5, Canada

R. J. Nelson

Institute of Ocean Sciences, Fisheries and Oceans Canada, 9860 West Saanich Road, P.O. Box 6000, Sidney, BC V8L 4B2, Canada

A. R. Sastri

Département des sciences biologiques, Université du Québec à Montréal, Montréal, QC H3C 3P8, Canada 
with key herbivores. (6) The epipelagic ecosystem is very efficient at retaining carbon in surface waters and preventing its sedimentation to the benthos. While enhanced PP could result in increased fish and marine mammal harvests for Northerners, it will most likely be insufficient for sustainable large-scale commercial fisheries in the Canadian Arctic.

\section{Introduction}

Climate-driven changes in primary production (PP) will have consequences for biogeochemical cycling, the success of top predators and the yield of harvestable resources in the Arctic Ocean. Marine animals depend on the primary synthesis of organic matter by photosynthetic microalgae in the water column (phytoplankton) or in the brine channels of ice (ice algae) (see Fig. 1 of Darnis et al. 2012). Different indices of marine food web productivity, ranging from zooplankton biomass to fish landings, are strongly correlated to estimates of primary production at regional (Ware and Thomson 2005) and global (Chassot et al. 2010; Conti and Scardi 2010; Irigoien et al. 2004; Nixon and Thomas 2001) scales. There is no reason a priori to expect otherwise in the Arctic Ocean. By fixing the greenhouse gas $\mathrm{CO}_{2}$, primary producers also stimulate the "biological pump", whereby sinking algae and detritus remove carbon from surface waters and help to alleviate the $\mathrm{CO}_{2}$ burden in the atmosphere.

In seasonally ice-covered polar seas, both ice algae and phytoplankton contribute to the PP that fuels the herbivorous food web (Horner and Schrader 1982). This production necessarily depends on the availability of two essential ingredients: light and nutrients. The classic seasonal description of primary production begins with the growth of shade-adapted ice algal cells (Ban et al. 2006) when critical minimum incident irradiance $\left(\sim 2-9 \mu \mathrm{E} \mathrm{m}^{-2} \mathrm{~s}^{-1}\right)$ is reached at the icewater interface in spring (Gosselin et al. 1986; Horner and Schrader 1982). In addition to the

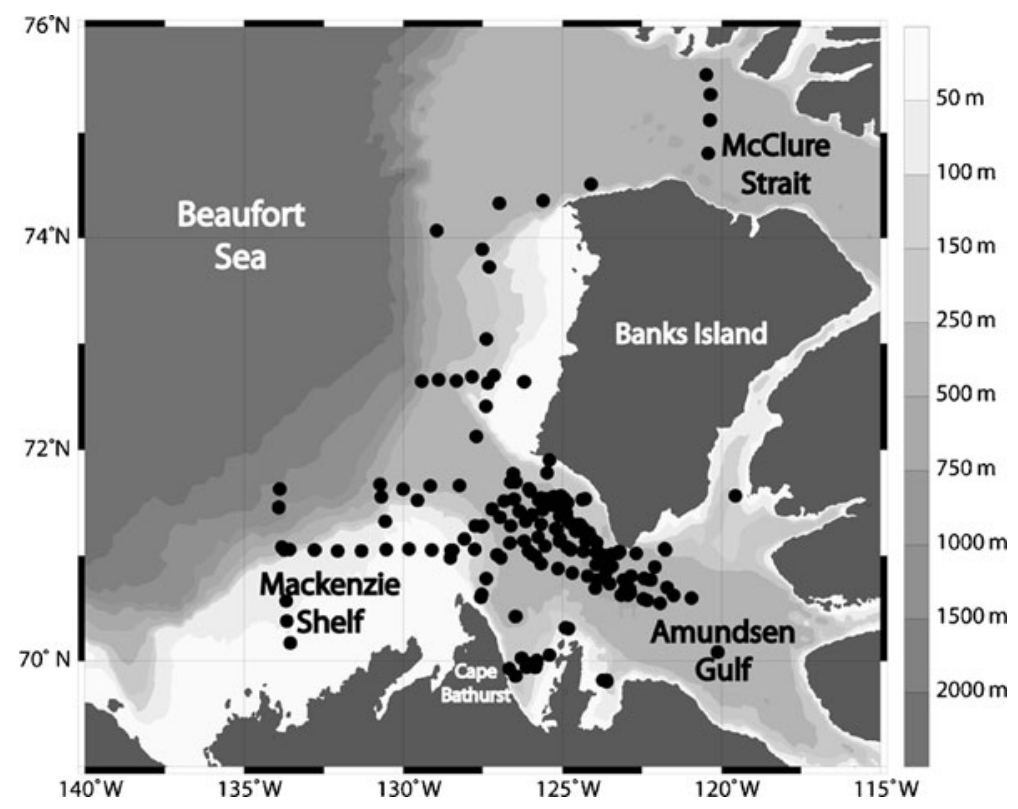

Fig. 1 Bathymetry of the southeastern Beaufort Sea with the location of stations (black dots) sampled between 15 October 2007 and 3 August 2008 as part of the International Polar Year-Circumpolar Flaw Lead System Study (IPY-CFL) 
fixation of carbon into particulate organic matter, this ice algal bloom releases large quantities of organic carbon readily usable by microbial consumers (Riedel et al. 2008). As conditions move from a bloom to a post-bloom phase at the end of ice algal production, an increasing amount of carbon is allocated to the synthesis of lipids in the cells (Lee et al. 2008). The onset of sea ice melt thus typically leads to the release of lipid-rich ice algae in the water column providing high energy food for the zooplankton and eventually the benthos, early during the season of arctic biological production. Phytoplankton then take over as the dominant primary producers and are responsible for most of total primary production on an annual basis (Gosselin et al. 1997). The intensity of the spring or early summer phytoplankton bloom depends on the availability of nutrients, which are readily depleted from the surface layer (Tremblay and Gagnon 2009). A period of relatively low production usually follows until the ice forms again. A second bloom may occur in the fall in polynyas where autumnal ice growth is delayed substantially (Tremblay and Smith Jr 2007).

The general "classic" view summarized above must now be considerably modified and enriched following two large IPY programs, the Circumpolar Flaw Lead System Study (CFL) and Canada's Three Oceans (C3O). These projects documented sharp contrasts in the timing, magnitude and composition of primary production between shelf environments and the deep offshore waters of the Canada Basin. In particular, the IPY projects provided knowledge to address the following key questions:

- What is the magnitude of primary production in different sectors of the Arctic and how does it respond to light and nutrients?

- How is this production distributed over time (phenology)? Does it occur in one or more pulses during the growth period?

- How much of this production occurs under the ice during spring when it is not visible to orbiting sensors?

- What are the major groups and species of primary producers responsible for this production?

- What is the "fate" or function of this production in the ecosystem-does it sink efficiently and fuel the benthic food web or is it readily consumed and transferred up the pelagic food web?

\subsection{International Polar Year-Circumpolar Flaw Lead System Study (IPY-CFL)}

The boundary between the central arctic moving pack ice and landfast sea ice in winter forms a continuous flaw lead system positioned over the extensive continental shelves surrounding the Arctic Ocean (Smith and Rigby 1981). This feature, called the circumpolar flaw lead system, widens as the clockwise Beaufort Sea ice gyre entrained by north-easterly winds and easterly currents diverges from the coastal fast ice (Proshutinsky et al. 2002). In the arctic marginal seas, complex physical processes can cause these flaw leads to enlarge and develop into recurrent polynyas, such as the Cape Bathurst and Laptev Sea flaw polynyas (Barber and Massom 2007). By experiencing reduced ice cover, these areas are highly sensitive to atmospheric and oceanic forcing, and become sites of enhanced ice production and brine release during the cold season (Williams et al. 2007). Latent heat fluxes driven by upwelling also increase the upward flux of nutrients, especially at the ice edges of large polynyas (Dunbar 1981). The combination of these physical processes contributes to nutrient replenishment in the euphotic zone (i.e. surface layer where there is enough light to support photosynthesis), contrasting with the ice-covered surrounding waters where a strong stratification usually prevents such deep mixing (Tremblay et al. 2008). Furthermore, 
reduced ice conditions result in additional solar radiation penetrating deeper in the water column over an annual cycle (Tremblay and Smith Jr 2007). Because of the longer growing season and increased availability of nutrients, polynyas are sites of enhanced biological productivity, which is illustrated by the occurrence of large populations of apex predators such as sea birds, seals, whales and polar bears (Stirling 1997; Tynan and DeMaster 1997). The circumpolar flaw lead system (a network of narrow polynyas) thus represents an ideal model to gain insights into the changing arctic marine ecosystem.

The CFL program, led by the University of Manitoba, was the largest Canadian-led international multidisciplinary research effort during IPY, bringing together over 350 participants from 12 countries (Barber et al. 2010). The program was designed to investigate how atmospheric, sea-ice, and oceanic processes are changing the nature of the flaw lead system, and how the marine ecosystem and related processes (nutrients, carbon and greenhouse gas fluxes, contaminant transport) will respond to these changes. The CFL study strongly built upon the expertise gained during the Canadian Arctic Shelf Exchange Study (CASES), the first scientific program to overwinter a research icebreaker in the southeastern Beaufort Sea. In contrast with CASES, where the overwintering site was in the landfast ice of Franklin Bay and represented a typical Canadian Arctic Archipelago winter ice environment, the CFL fieldwork focused on the Cape Bathurst polynya complex. The research icebreaker CCGS Amundsen remained mobile throughout the winter of 2007-2008 and a total of 293 continuous sampling days in the region provided a remarkable opportunity to study the winter and spring dynamics of the CFL ecosystem (Fig. 1).

\subsection{International Polar Year-Canada's Three Oceans project (IPY-C3O)}

The oceans surrounding Canada are inextricably tied to each other and to the global climate system. Canada's Three Oceans (C3O) was an IPY project led by Fisheries and Oceans Canada which characterized the physics, geochemistry and biology of the Arctic, subarctic Pacific and subarctic Atlantic oceans. The goal of the program was to provide baseline information for the assessment of change as well as the stability of the boundaries between each region. Spatial variability was assessed along a 15,000 km ocean transect travelled by the two science-equipped Canadian Coast Guard icebreakers Louis S. St. Laurent and Sir Wilfrid Laurier (Fig. 2). Moorings placed at core locations provided information on the temporal variability of key parameters. To provide a backdrop for examination of this vast tripartite ocean network, it was conceptually divided into 22 regional domains (see Carmack et al. 2010). Work carried out during $\mathrm{C} 3 \mathrm{O}$ dovetails into the ongoing research of the Joint Ocean Ice Study/Beaufort Gyre Observing System (JOIS/BGOS) project in the Canada Basin (Proshutinsky et al. 2009). The two years of C3O field operations integrated the work of an international group of over 141 science personnel conducting 40 different projects examining physics, geochemistry and biota from viruses to whales.

\section{Results and discussion: primary production dynamics: a comparison between the deep basin and the continental shelves in the pan-Arctic}

\subsection{The Canadian Arctic in a global perspective}

Estimates of annual marine PP span two orders of magnitude in the World Ocean, ranging from $\sim 5-15 \mathrm{gC} \mathrm{m}^{-2}$ in the central High Arctic (Gosselin et al. 1997; Rysgaard et al. 1999) to $\sim 1200-1500 \mathrm{gC} \mathrm{m}^{-2}$ in the most productive coastal upwelling systems (Nixon and Thomas 


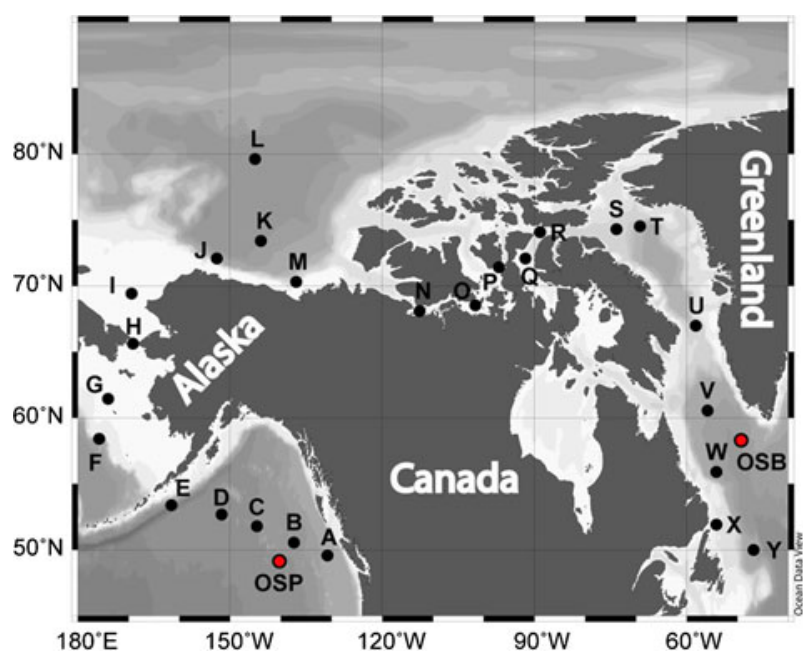

Fig. 2 Location of stations sampled during the IPY C3O and JOIS/BGOS programs. OSP and OSB refer to Ocean Station Papa and Ocean Station Bravo, respectively

2001) (Fig. 3). Although irradiance exerts a strong control on the timing and seasonality of PP at high latitudes, first-order differences in productivity (i.e., oligotrophic versus eutrophic) and fisheries yield at the global scale are controlled by nutrient supply. Removing ice from the Arctic during summer may increase PP (Arrigo et al. 2008; Pabi et al. 2008), especially in areas formerly occupied by multi-year ice, but the overall trophic state of the ocean will not shift unless the upward supply of nutrients per unit area increases significantly. A comparison with other stratified systems at low latitudes is especially informative;

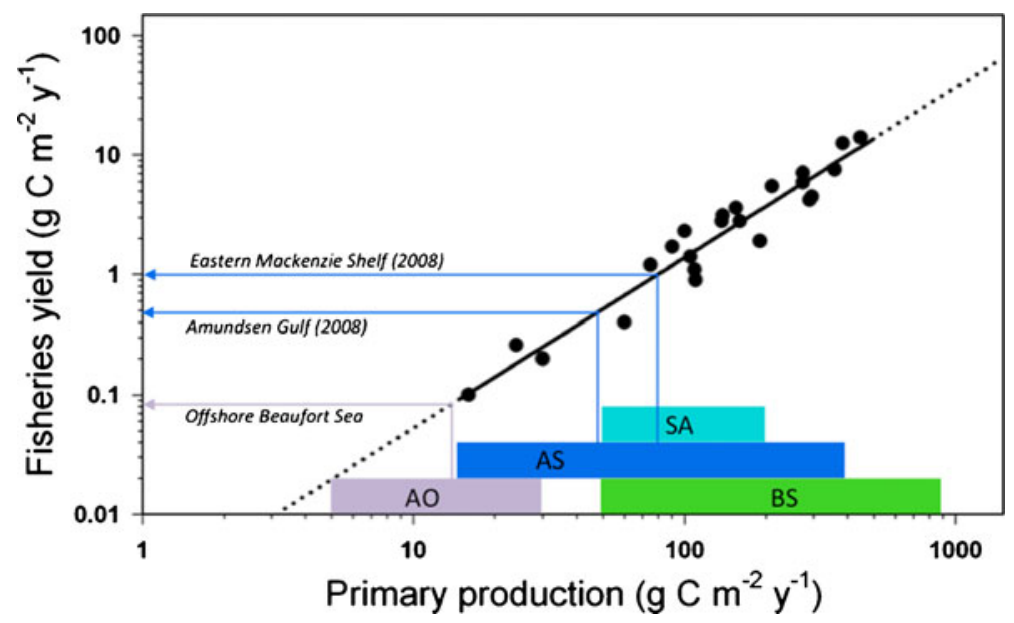

Fig. 3 Global relationship (data points) between fisheries yield, measured as fish landings, and annual primary production (adapted from Nixon and Thomas 2001) with respect to the average (position of the acronyms) and range (horizontal boxes) of $\mathrm{PP}$ values for different sectors of the Arctic $(\mathrm{AO}=$ central High Arctic; $\mathrm{AS}=$ peripheral arctic shelves; $\mathrm{SA}=$ Atlantic sector; BS = Bering Sea) as reported by (Sakshaug 2004). The elbow lines and arrows project the hypothetical commercial fisheries yields that could be supported by the annual PP estimated during IPY-CFL and previous programs in the southeastern Beaufort Sea 
while irradiance is unlimited in the tropics, offshore PP levels remain one order of magnitude below those of upwelling regions. It follows that irradiance subsidies should have a maximum impact on net PP in arctic areas where nutrient renewal is substantial, but weak or no effect in oligotrophic regions (Ardyna et al. 2011).

The vertical supply of nutrients is determined by the interplay between atmospheric forcing (convection, wind drag) and the stability or stratification of the upper water column. The central High Arctic is home to the most strongly stratified marine waters by a large margin (Carmack 2007), much more so than the tropical regions usually considered as models of stratified conditions. Because stratification in the Arctic is mostly due to river discharge and the influx of low-salinity water from the Pacific Ocean (Yamamoto-Kawai et al. 2008), it will persist despite the ongoing loss of sea-ice, whose formation and melting affects the depth and strength of the seasonal pycnocline. A review of seasonally ice covered arctic seas showed that PP decreases from the least-stratified peripheral seas (Barents Sea, Bering Sea) to the strongly stratified High Arctic (Beaufort Sea), not because the latter receives less irradiance but because it is nitrogen-depleted (Tremblay and Gagnon 2009). Recently, Martin et al. (2010) showed that the combination of strong stratification and low nitrate in the upper euphotic zone favours the early appearance and seasonal persistence of a widespread subsurface chlorophyll maximum (SCM) across the Canadian High Arctic. Phytoplankton in the SCM are photosynthetically competent and can account for at least $50 \%$ of the annual new production in the water column (Popova et al. 2010; Tremblay et al. 2008), which poses a challenge to remote sensing estimations of PP in this region (Martin et al. 2010).

Despite low average productivity, the potential for high PP north of the Arctic Circle clearly exists in polynyas and seasonally ice-free regions influenced by atmospheric systems that induce upwelling and upward nutrient supply (Tremblay et al. 2002, 2006b; Wassmann et al. 1999). Other regions of moderately elevated PP or chlorophyll biomass occur at bathymetric discontinuities (Carmack and McLaughlin 2011), oceanic fronts (Ben Mustapha et al. 2010) and, possibly, in association with anticyclonic eddies (Mathis et al. 2007; Tremblay et al. 2008) or internal waves (Rainville and Woodgate 2009). Conditions of unconsolidated sea-ice cover during winter, such as those observed in 2008 during IPY-CFL, may favour mixing and accrued upward supply of nitrate (Forest et al. 2011), which is consistent with the doubling of PP from $21 \mathrm{gC} \mathrm{m}^{-2}$ under conditions of reduced mixing in 2004 (Brugel 2009) to $49.2 \mathrm{gC} \mathrm{m}^{-2}$ during CFL.

Under the $\mathrm{C} 3 \mathrm{O}$ program, large-scale snapshots of phytoplankton biomass and productivity were obtained at 42 stations along transects that extended from the NW Labrador Sea, across Baffin Bay and the Canadian Arctic Archipelago to Coronation Sound in 2007, and from the coastal NE Pacific (vicinity of SW Vancouver Island) across the Bering, Chukchi and south Beaufort Seas to Coronation Sound in 2008 (Fig. 4). In 2007, as part of JOIS, measurements were also conducted in the Canada Basin. Productivity showed the expected patterns for the NE Pacific Ocean, with higher PP along the coastal areas and lower in the High Nutrient-Low Chlorophyll (HNLC) open waters, with an average of $0.55 \mathrm{gC} \mathrm{m}^{-2} \mathrm{~d}^{-1}$. Productivity was elevated in the shallow north Bering and Chukchi seas and principally in the vicinity of the Barrow Canyon where upwelling occurs, but further decreased in the Southern Beaufort Sea and the Canada Basin. Average depth-integrated PP in the Bering/ Chukchi region was $1 \mathrm{gC} \mathrm{m}^{-2} \mathrm{~d}^{-1}$, and new production (i.e. the portion of total PP supported by nitrate uptake) was $\sim 57 \%$ of PP, which was the highest recorded during $\mathrm{C} 3 \mathrm{O}$. In contrast, the lowest depth-integrated total phytoplankton production was measured in the southern Beaufort Sea/Canada Basin region, with an average of $0.05 \mathrm{gC} \mathrm{m}^{-2} \mathrm{~d}^{-1}$ of which only $\sim 26 \%$ was new production. The Canadian Arctic Archipelago and the Baffin Bay/Davis Strait regions were characterized by large variability in PP due to the heterogeneity of the areas 


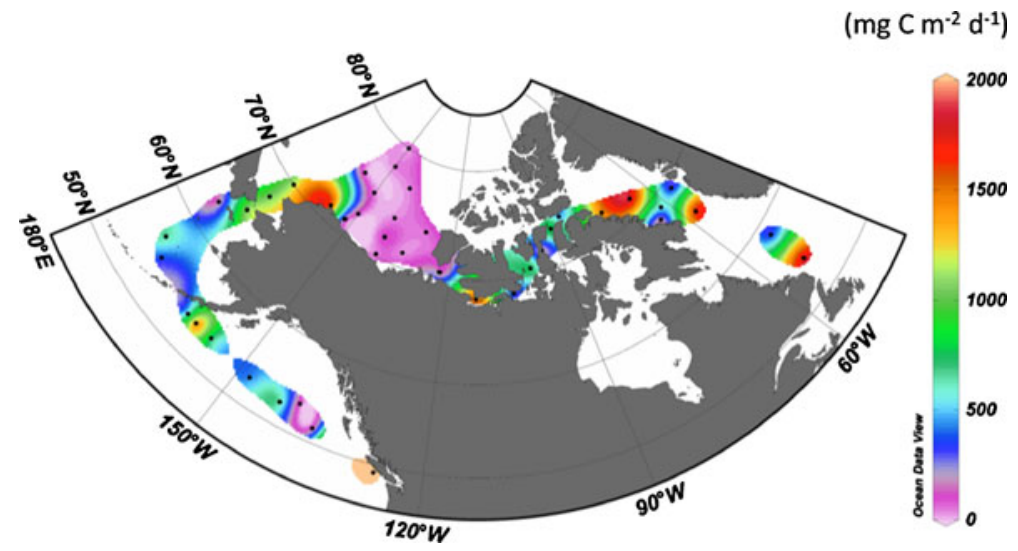

Fig. 4 Snapshot of large-scale, pan-arctic distribution of daily primary production integrated over the euphotic zone obtained during the IPY-C3O program (Varela et al. in prep.)

sampled in terms of bathymetry, sea ice cover, vertical mixing and currents (Carmack and McLaughlin 2011). Phytoplankton productivity ranged between 0.2 to $1.8 \mathrm{gC} \mathrm{m}^{-2} \mathrm{~d}^{-1}$ within these two regions, with averages of $0.7 \mathrm{gC} \mathrm{m}^{-2} \mathrm{~d}^{-1}$ in the CAA and $1 \mathrm{gC} \mathrm{m}^{-2} \mathrm{~d}^{-1}$ in Baffin Bay/Davis Strait. The C3O project thus provided a valuable pan-arctic perspective of phytoplankton dynamics for two years, which should be helpful for future comparison.

The IPY-CFL program assessed the impact of two types of upwelling that add considerable intra-regional and temporal variability to PP in the coastal Beaufort Sea. Mundy et al. (2009) documented an ice-edge upwelling event that brought nutrient-rich waters to the surface during June 2008 and induced a phytoplankton bloom that produced $\sim 31 \mathrm{~g} \mathrm{C} \mathrm{m}^{-2}$ of new production over three weeks. This production was approximately twice that of previous estimates for annual production in the region (Tremblay et al. 2008). Using a unique combination of in situ and remote sensing approaches, Tremblay et al. (2011) showed how the wind patterns that induced rapid sea-ice loss in the Beaufort Sea in 2007 triggered massive and repeated upwelling of deep nutrient-rich waters, multiplying the yield of ice algae, phytoplankton, zooplankton and benthos by two-four fold in Franklin Bay and the adjacent Mackenzie shelf. Such events are likely to become more common with the greater incidence of upwelling-favourable winds and the increasingly frequent and far seaward retreat of the central ice pack, which exposes the shelf break to direct wind forcing (Yang 2009). The strength of upwelling events is also bound to rise as extreme wind events gain in intensity (Zhang et al. 2004), increasing inshore-offshore PP gradients and making the shelves conspicuous oases for consumers.

While remote sensing data suggest a modest increase in the annual PP of the offshore Beaufort Sea (Arrigo et al. 2008), other time series including C3O data from the Canada Basin suggest the reverse or a lack of change (Li et al. 2009; McLaughlin and Carmack 2010). Others argue that the recent decrease in $\mathrm{CO}_{2}$ uptake capacity in the western Canada Basin is incompatible with rising PP levels (Cai et al. 2010). Despite this apparent contradiction, which likely arises from differing levels of accuracy and windows of spatial and temporal observation, it is clear that offshore waters are not as responsive as coastal ones, in terms of PP per unit area. Tremblay et al. (2011) showed that the strong winds that induced coastal upwelling in summer 2008 failed to erode the vertical stratification and stimulate PP immediately offshore. The strength of this stratification has increased by $25 \%$ in $2007-$ 2009, marking an acceleration of the decadal trend (McLaughlin and Carmack 2010). The 
greater stratification further constrains the already weak upward supply of nutrients to the euphotic zone. A concomitant increase in water convergence in the Beaufort Gyre has deepened the nitracline (i.e. depth where the vertical gradient in nitrate concentration is strongest) and the depth of the SCM (McLaughlin and Carmack 2010). Such changes are expected to negatively affect PP as long as the Arctic Oscillation remains anticyclonic and freshwater continues to be stored in the Beaufort Gyre. Although phytoplankton biomass has not yet changed, the relative contribution of small-sized algae (picophytoplankton) to the total has increased ( $\mathrm{Li}$ et al. 2009). Because continuity dictates that upwelling on the shelf be compensated by downwelling off-shelf (Yang 2009), the latter might further decrease PP immediately offshore.

Simple projections based on a global relationship between PP and fisheries yield (Nixon and Thomas 2001) suggest that even the most productive waters associated with shelf-break upwelling would support relatively low fish catches compared to other fisheries of the World Ocean (Fig. 3). In offshore waters or on shallow shelves in the absence of upwelling, PP would need to increase by nearly two orders of magnitude to sustain commercial fisheries, which is highly unlikely. These coarse projections ignore other unique aspects of the arctic setting, such as the temporal distribution of PP within a year and the ecological efficiency of its transfer to upper trophic levels. Those will be explored in the next sections.

\subsection{Regional characteristics of primary production in the Canadian High Arctic}

\subsubsection{Size or species composition}

The contribution of diatoms (a group of large-sized and nutritious (or palatable) phytoplankton) to primary production generally increases with total production (Chisholm 1992), favouring the efficient and relatively direct transfer (i.e., involving few feeding steps) of photosynthetically fixed organic matter to top predators and, if applicable, commercial fish stocks (Conti and Scardi 2010; Cushing 1989). In the most productive upwelling regions, the direct consumption of large-sized diatoms by large zooplankton and fish leads to high ecological efficiency and high fisheries yields. At the low end of the spectrum, primary production is typically dominated by very small algae that do not foster large aggregations of fish, birds and marine mammals. Although diatoms generally dominate when productivity is high, they can be replaced by other groups of phytoplankton that are less palatable to grazers and maintain high biomass levels, excluding other photosynthetic plankton. Among these bloom-formers are particular species of Phaeocystis and Emiliania, a coccolithophore. However, factors that control the success and geographical range of such species in the northern hemisphere are poorly understood (Schoeman et al. 2005). To date, no blooms of these species have been observed in the Canadian High Arctic. However, there has been a shift in phytoplankton assemblage with increasing abundance of small phytoplankton, mostly one ecotype of Micromonas pusilla (Lovejoy et al. 2007) and a concomitant increase in heterotrophic bacterioplankton in the offshore Canada Basin in recent years ( $\mathrm{Li}$ et al. 2009). These and other changes in the taxonomic composition of Archaea and bacteria (Comeau et al. 2011) indicate that the microbial component of the food web has become more persistent and that the ecological efficiency of carbon transfer between PP and apex consumers may be diminished.

These analyses do not take into account the spring-summer transition when the diatombased autotrophic component of the food web would be predicted to be the most pronounced. Using molecular techniques, Terrado et al. (2011) found that in late March the active phytoplankton community was taxonomically made up of Micromonas and larger 
mixotrophic dinoflagellates. Diatoms increased in abundance by mid-April but by the beginning of May heterotrophic protists and parasites were more active although diatoms continued to dominate photosynthetic biomass.

Because diatoms typically flourish when ambient nutrient concentrations are high (Sarthou et al. 2005), their periodic success in the coastal Arctic during spring is probably linked to the lack of nutrient consumption during winter. The combination of ice and low or absent solar irradiance during winter prevents photosynthesis, so that nutrients slowly accumulate at the surface due to decomposition and turbulent upward supply. During IPY$\mathrm{CFL}$, nitrate increased from non-detectable levels in November to $3.6 \pm 0.8 \mu \mathrm{M}$ at the onset of the growth season, creating a favourable environment for diatoms. This accumulation does not occur at low latitudes, where irradiance is always high and the slow trickle of nutrients supplied by upward diffusion is readily used by small-sized phytoplankton adapted to low nutrient levels. The relatively shallow position of the nitracline with respect to the euphotic zone may also be beneficial to diatoms. Martin et al. (2010) showed that coastal SCM occur at or near the nitracline at light levels corresponding to 3-10\% of incident irradiance at the surface. At low latitudes, SCM communities are found deeper in the euphotic zone ( $\leq 1 \%$ of incident light at the sea surface) and are typically associated with lower nutrient availability and diatom abundance than their arctic counterparts. A similar situation now seems to apply to the offshore Canada Basin, where the SCM has deepened by $\sim 18 \mathrm{~m}$ since 2002 (McLaughlin and Carmack 2010).

\subsubsection{Timing of ice-algal and pelagic production}

So far we have discussed the magnitude of PP, but the distribution of production over a yearly cycle has strong impacts on consumers, ecosystem services and the accuracy of remote sensing estimation of marine productivity. A recent review indicated that fisheries yield and the average trophic level (TL) of catches are related to the extent of intra-annual temporal variability in PP across Large Marine Ecosystems (Conti and Scardi 2010). The TL of the catch ranges from $\sim 2.7$ for small pelagic fish with a mixed diet of phytoplankton and zooplankton, to $\sim 3.8$ for demersal fish feeding primarily on smaller fish and large invertebrates. Pelagic-dominated (low TL) harvests produce the highest yields in marine fisheries, while fisheries yield is relatively low and based on catches with intermediate TL under conditions of high PP variability. The average TL of arctic cod (Boreogadus saida) is 3.6 (Hobson et al. 2002). While the fundamental ecological process underlying such empirical relationships is not clear, the patterns strongly suggest that strong seasonal pulsing in PP lowers the overall ecological efficiency of transfers from phytoplankton to fish.

According to a longstanding paradigm, the relatively short growing season in the Arctic implies that consumers have a narrow window of opportunity to grow and accumulate energy reserves for winter survival and/or reproduction (Loeng et al. 2005). Due to its extreme seasonality, the High Arctic might be considered as a lower bound for the intermediate TL-low fish yield scenario proposed by (Conti and Scardi 2010) and fish production in the Beaufort Sea may be even lower than hypothetical projections (Fig. 3). On the other hand, the anomalously high contribution of large-sized or colonial diatoms to PP in coastal waters may compensate.

The last decade of large scale programs, including IPY-CFL, in the Canadian Arctic has greatly increased our understanding of the timing and intra-annual variability of PP (Fig. 5). On the right hand side, the baseline scenario for offshore waters shows the strong link between the timing of ice break-up, the end of ice-algal production (IAP) and the onset of a single pulse of pelagic PP. These pulses are relatively weak and short-lived due to the modest 


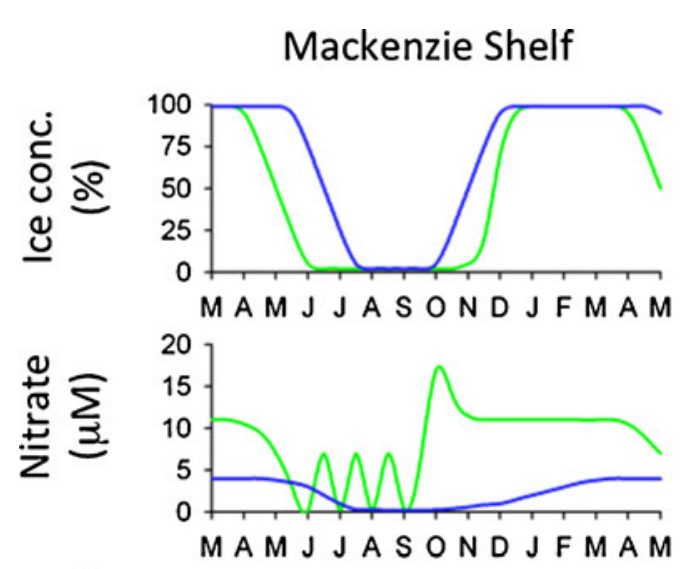

\section{Offshore Canada Basin}
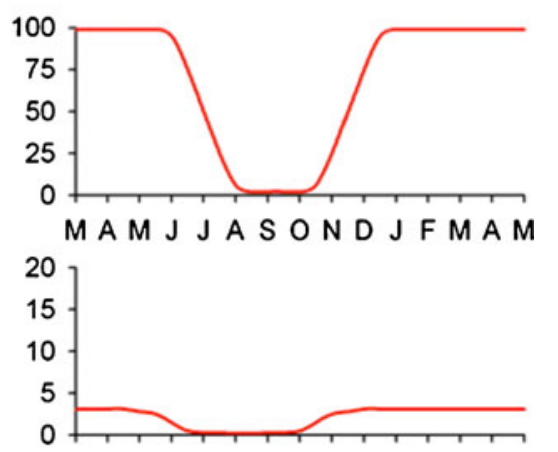

MAM J J A S N D J F M M
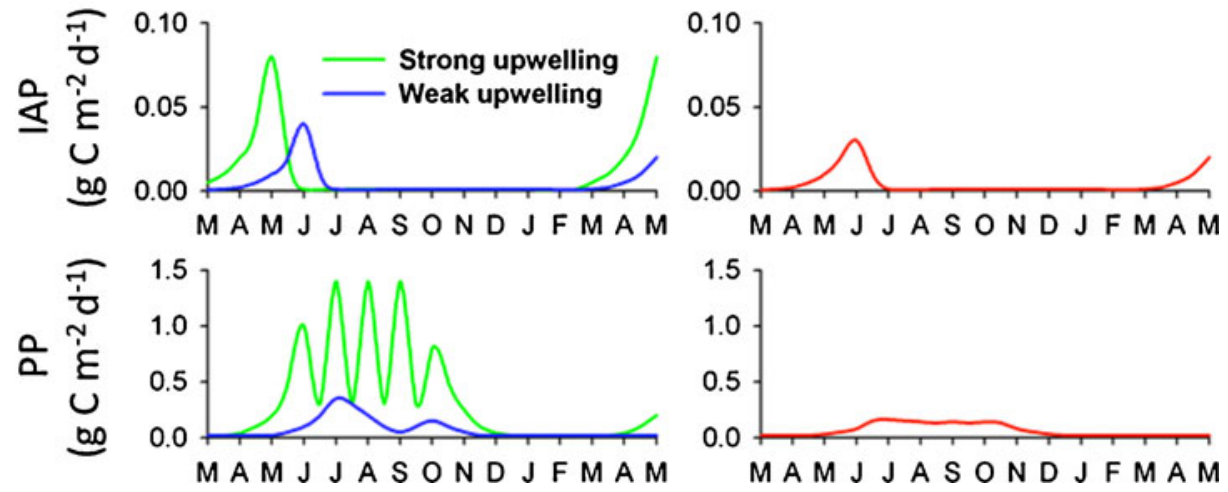

Fig. 5 Schematized time series of ice concentration, nitrate concentration at the surface, ice-algal production (IAP) and phytoplankton production in the offshore Beaufort Sea (right hand side) and during strong (green lines) and weak (blue lines) upwelling years in waters of the coastal Beaufort Sea (left hand side) based on data from IPY-CFL (Tremblay et al. 2011) and previous programs (Tremblay et al. 2008) in the southeast Beaufort Sea

upward supply of nitrate during winter and the ensuing contribution of the SCM to annual production. Here we only present an average scenario that ignores any localized impacts of internal waves and eddies on PP. For the Beaufort shelf, PP depends on wind forcing and the two scenarios depicted on the left hand side of Fig. 5 schematize the extremes of a continuum of possible combinations. During periods of strong upwelling, such as prevailed during IPY-CFL from fall 2007 to summer 2008, winds induce ice divergence from protruding land masses (e.g. Cape Bathurst and Cape Parry) and increase the duration of the growth season on the eastern shelf. Nutrients are injected episodically to the surface and are followed by lagging PP pulses throughout the summer. When upwelling takes place in the fall, phytoplankton can use only a fraction of the nutrients as solar irradiance declines rapidly following the equinox. The nutrients that are not used over the winter are available to support both IAP and PP in the spring. The spring production from autumnal nutrient input is greater than what would be otherwise supported by upward turbulent supply or mixing (Tremblay et al. 2008). Since upwelling occurred both in the fall and in the following summer during IPY-CFL, PP data for 2008 represent the higher end of possible values. Note that the overall importance of upwelling on such a narrow shelf is likely greater than it would be on the much broader Siberian shelves. 
The final biomass of ice algae is strongly linked to nutrient availability in the Arctic (Gradinger 2009). While intuitively IAP would be negatively affected by the ongoing contraction of the ice-covered period, the upwelling of nutrients in the fall actually favours the contrary and ultimately could increase the vertical transfer of ice algae to the benthos (Tremblay et al. 2011), as long as ice break-up does not occur before ice algae reach their maximum biomass in the spring. This scenario is likely to prevail for some time since most of the increase in the duration of growth season is due to late freeze-up as opposed to early melt (Markus et al. 2009) and the incidence of upwelling favourable winds, which are usually strongest from October to December, has increased since 1978 (Yang 2009). In addition to coastal upwelling, ice-edge upwelling events during early summer may promote IAP (Mundy et al. 2009), depending if ice algae are still attached at that time of the year.

The implications of upwelling for PP are generally more direct than for IAP. While the number and intensity of upwelling events may vary from year to year (Williams and Carmack 2008; Yang 2009), their succession promotes a punctuated supply of organic matter for herbivores over the growth season. This pattern implies that coastal zooplankton, such as the keystone herbivorous copepod Calanus glacialis, are released from constraints imposed by a single pulse of PP. A strong and early initial pulse of PP (and IAP) would promote higher reproduction rates (Soreide et al. 2010) by enabling females to mature rapidly and to produce larger egg clutches. Ensuing PP pulses would then favour recruitment and increase maturation of the year's cohort into CIII and CIV copepodites. The level of new $\mathrm{PP}$ on the shelf during strong upwelling years is in the upper range of values observed for the Barents Sea during productive years when storms episodically mix the water column. If there is a place in the western Canadian Arctic where fisheries have the slightest chance to be established it would be the Mackenzie shelf where upwelling events are most common.

Finally, the timing of PP has important implications on the accuracy of remote sensing estimates of marine productivity. The development of significant phytoplankton biomasses under the ice was well documented during IPY-CFL. The penetration of light under the ice was significant during the ice-edge upwelling that occurred in Darnley Bay (Mundy et al. 2009). Water-column PP amounted to $0.31 \mathrm{gC} \mathrm{m}^{-2} \mathrm{~d}^{-1}$ and contributed up to $22 \%$ of the daily averaged production during the ice-edge bloom. Likewise, Tremblay et al. (2011) showed that substantial nitrate consumption occurred under the fast ice in Franklin Bay and roughly half of PP from April to July was not detected by orbiting sensors. Offshore, in the surface phytoplankton bloom began under $90 \%$ ice cover and reached its maximum biomass under $40 \%$ (Forest et al. 2011). Under-ice blooms are probably widespread yet poorly documented phenomena, which could gain in importance with the thinning ice cover and subsequent increase in transmitted irradiance to the water column. The rapid onset of the SCM in this context may lead to a further underestimation of PP by current remote sensing algorithms. This underestimation is likely to be more important in unproductive waters of the Beaufort Sea than in the more productive waters of the Chukchi Sea and Northern Baffin Bay, where a large portion of annual PP occurs in the upper euphotic zone due to substantial nutrient renewal at the surface (e.g., Tremblay et al. 2006b).

\subsection{Fate of primary production}

A variable and often unknown portion of PP is consumed by zooplankton in marine ecosystems. The portion of particulate PP that escapes zooplankton constitutes a detritus pool that sinks to the deep ocean or the benthos in shallow regions. Conceptually, that carbon sink can be viewed as a leftover of biological consumption in the upper ocean (Wassmann 1998). In addition to the detritus pool is dissolved organic material (DOM) that 
has evaded immediate remineralization by bacteria and other constituents of microbial food webs. The production, consumption and regeneration cycles in the pelagic zone are reflected in the quantity and quality of vertically exported biogenic matter leaving the euphotic zone. This export and its regulation are expected to depend on the activity of key pelagic zooplankton species, which in turn depend on the quality and timing of primary production pulses. In practice, resolving these processes requires a comprehensive multidisciplinary sampling approach.

A first comprehensive synthesis of carbon flows in the Canadian Arctic was done for the North Water Polynya (NOW) (Tremblay et al. 2006a). Because of uncertainties in estimates of productivity, consumption and vertical export, the synthesis capitalized on the good agreement among independent flux estimates to produce a plausible portrait of seasonal carbon flows. During IPY-CFL, this approach was improved by planning crucial ship-based experiments a priori and, most importantly, by using an inverse model that assimilated all available field data and rate constants from the literature to produce a least-square statistical solution for the major carbon flows within Amundsen Gulf (Forest et al. 2011). These flows are summarized in Fig. 6 using a form that makes them directly comparable to the less complete picture obtained for the NOW. This comparison is useful in a context of climate change, because the NOW is highly productive compared to the southeastern Beaufort Sea.

The synthesis produced by Forest et al. (2011) for Amundsen Gulf combined ship-based IPY-CFL data on bacterial production, zooplankton biomass and respiration, herbivory, bacterivory, vertical particle fluxes, pools of particulate and dissolved organic carbon (POC, DOC) and net community production (NCP). A summary is presented here. Between
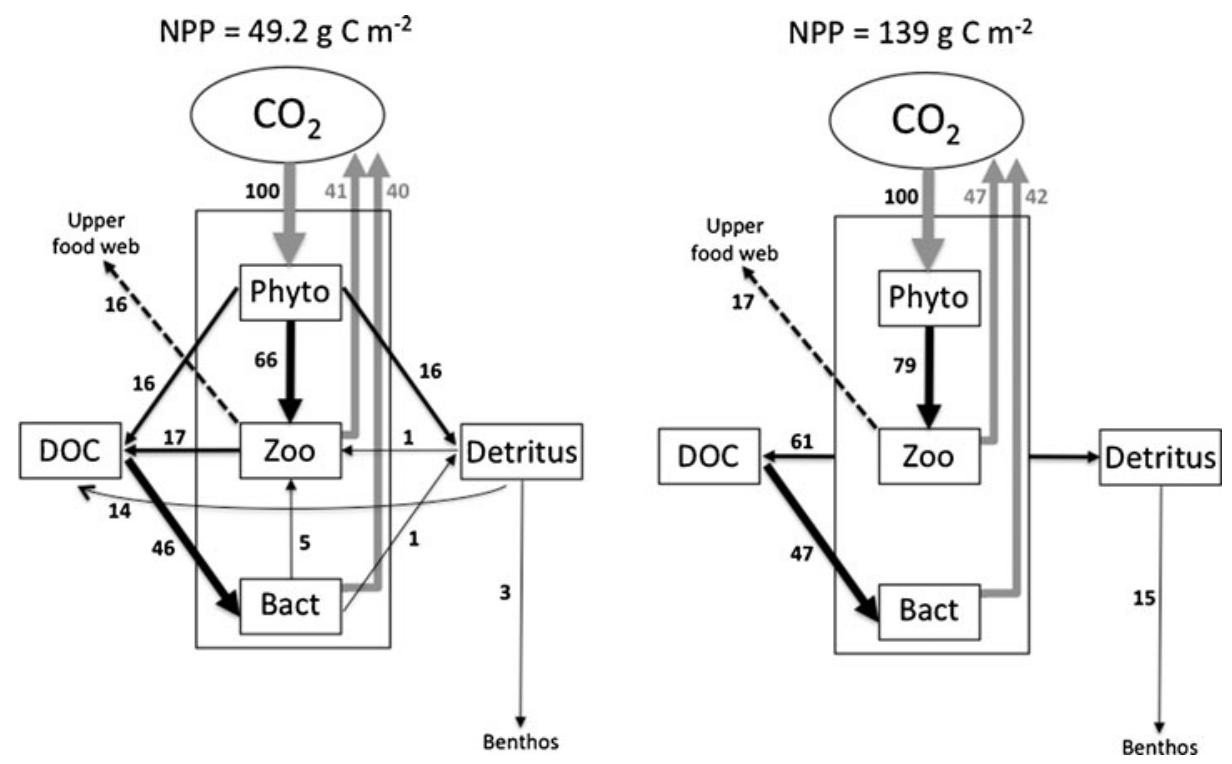

Fig. 6 Summary of carbon fluxes (all in $\mathrm{gC} \mathrm{m}^{-2}$ ) from net primary production (NPP) to key organisms and reservoirs from March to August in Amundsen Gulf (based on Forest et al. 2011) and the North Water Polynya (based on Tremblay et al. 2006a). Gray arrows indicate gas fluxes to (NPP) and from (respiration) organisms. Solid black arrows represent fluxes of organic matter across the lower food web and the dashed arrows give the potential flux of carbon toward apex consumers. Note that the different fluxes may not perfectly add up due to missing components 
February and August 2008, ice algae and phytoplankton accounted for $6.4 \%$ and $93.6 \%$ of gross primary production $\left(52.5 \pm 12.5 \mathrm{gC} \mathrm{m}^{-2}\right)$, respectively. The inverse model estimated a net primary production (NPP) of $49.2 \mathrm{gC} \mathrm{m}^{-2}$, around half of which (52\%) was ingested directly by mesozooplankton and an additional $14 \%$ by microzooplankton. The remaining portion of NPP (34\%) was split evenly between the DOC and detritus pools. As much as $81 \%$ of NPP was returned to $\mathrm{CO}_{2}$ via bacterial (40\%) and zooplankton (41\%) respiration, $3 \%$ escaped the euphotic zone as sinking detritus (a mixture of algal cells, fecal pellets and other organic matter) and $16 \%$ passed into "residual" C pools (net production or biomass increment of phytoplankton, detritus, zooplankton and DOC). As much as $76 \%$ of this residual C flux (or $16 \%$ of NPP) was attributed to zooplankton and represents the carbon available for transfer to the next trophic level, such as planktivorous fish (e.g., arctic cod), bowhead whales and birds. Note that since we ignore the minute residual pools of bacterial biomass, particulate organic carbon and DOC resolved by the model, the various fluxes depicted in Fig. 6 do not perfectly tally.

The ecological efficiency of the $\mathrm{C}$ transfer from PP to primary consumers in Amundsen Gulf was as high as $21.4 \%$, which is typical of the most productive upwelling systems. A similar situation prevailed in the NOW despite a three-fold difference in primary production (Tremblay et al. 2006a). The vertical flux of organic matter out of the upper ocean (defined as $50 \mathrm{~m}$ in NOW and $80 \mathrm{~m}$ in IPY-CFL) was also small and remarkably similar in the two systems when accounting for the difference in depth horizons. This comparison shows that the size of all major fluxes increases with overall productivity, but the qualitative nature or pathways of these flows does not change appreciably.

The IPY-CFL data confirmed that High Arctic pelagic systems maintain low seasonal export efficiencies (defined as the ratio of export to PP) along a three-fold productivity gradient. These efficiencies are in fact comparable to those obtained on a daily basis in relatively stable tropical environments (Buesseler 1998). Daily comparisons of PP and export in pulsed environment are much less meaningful and the comparison of post-bloom PP values with export may have given the illusion of very high export efficiencies in the Arctic (Buesseler 1998). Clearly, arctic zooplankton are very proficient at harvesting PP and making the most of the ice-free season. The actual residual $\mathrm{C}$ flow resulting from zooplankton growth (including nauplii and larger heterotrophic protists), after accounting for trophic interactions, suggests that vertebrates had access to a maximum of $6.6 \mathrm{gC} \mathrm{m}^{-2}$ (i.e., $13.4 \%$ ecological efficiency). This transfer efficiency is presumably in the upper range of "environmentally possible" values for the central Amundsen Gulf region since it was obtained during a year of low ice coverage, warm sea surface temperature and enhanced PP. Nevertheless, it is much lower than the absolute production required for sustaining commercial fish catches $\left(15-130 \mathrm{gC} \mathrm{m}^{-2} \mathrm{yr}^{-1}\right)$ as recorded throughout large marine ecosystems (Conti and Scardi 2010).

From the climatic perspective, the depth at which $\mathrm{CO}_{2}$ is released by planktonic respiration dictates whether the initial PP could potentially return back to the atmosphere within a year or be stored for at least a decade or even hundreds of years. This is because the average residence time of Pacific water ( $\sim 50-200 \mathrm{~m}$ depth) in the Beaufort Sea is estimated to be 11 years (Yamamoto-Kawai et al. 2008) and that of Atlantic and deep waters ( $>250 \mathrm{~m}$ depth) to be approximately 30 to 300 years (Gregor et al. 1998). Unfortunately, discrepancies in the sampling depth or incomplete coverage of the water column in the various datasets, as well as uncertainties related to zooplankton diel vertical migration (e.g., Fortier et al. 2001) prevented the conception of a multi-layer $\mathrm{C}$ flow model during IPY-CFL. The intermittent on-shelf upwelling of Amundsen Gulf intermediate waters ( $\sim 33$ salinity) during spring and summer 2008 (Tremblay et al. 2011), which are supersaturated with respect to atmospheric 
$\mathrm{CO}_{2}$, might complicate assessments of the ultimate fate of the $\mathrm{C}$ respired over our sampling period. However, measurements of surface water $\mathrm{CO}_{2}$ concentrations $(0-50 \mathrm{~m}$ depth) and subsequent air-sea flux computations confirmed that central Amundsen Gulf acted as a sink for atmospheric $\mathrm{CO}_{2}$ at the annual scale in 2007-2008 (Shadwick et al. 2011). Future studies of $\mathrm{C}$ fluxes in the region should thus aim at using a finer vertical resolution, especially since plankton respiration rates are expected to increase in response to arctic warming in springsummer (Vaquer-Sunyer et al. 2010).

\section{Conclusion}

Comprehensive annual (CFL) and quasi-synoptic (C3O) surveys of ecosystem data remain scarce in the Arctic Ocean. Here we strove to exploit this rare data to the fullest but acknowledge that the spatial snapshots do not resolve seasonality and that the inter-annual comparisons based on CFL and CASES include two years only. Our analysis nevertheless provides crucial insights that question long-standing paradigms and allow to formulate hypotheses on the nature of ongoing environmental and ecosystemic change in the Arctic Ocean.

Apart from the decrease in summer sea-ice cover, one of the most spectacular effects of the changing arctic environment is the acceleration of surface layer stratification (McLaughlin and Carmack 2010). With the exception of specific areas characterized by upwelling, increased stratification results in additional warming and freshening of surface waters, and in the decrease of nutrient supply to the euphotic zone. These conditions will have a large impact on the dynamics of primary production, as they benefit small picophytoplankton cells (e.g., Micromonas) over large diatoms ( $\mathrm{Li}$ et al. 2009). Along with this shift in primary production, a significant increase in heterotrophic bacterioplankton has been observed in recent years ( $\mathrm{Li}$ et al. 2009). Through bottom-up processes, the displacement of large phytoplankton cells and increased carbon cycling within the microbial loop will likely affect large Calanus copepods, which constitute the main trophic link towards arctic cod, seabirds and marine mammals (Darnis et al. 2012). Moreover, increased pelagic turnover is expected from increasing heterotrophic bacterioplankton and mesozooplankton production and respiration, limiting the export of organic matter to the benthos.

Three paradigms pertaining to the lower food web in the Arctic Ocean must be revisited. The first of those is that the Arctic Ocean is a ubiquitously light-limited ecosystem. While this is true during the polar night or under the remnants of thick multi-year ice, we have shown that differences in the trophic status of adjacent seasonally ice-free areas is dictated by nitrogen availability during the growth season. Within a given area, however, a longer ice-free season increases the probability of episodic nutrient re-supply and prolongs exposure of the water column to sunlight, providing more energy and time for phytoplankton to exploit available nutrients at the surface and/or at the SCM. This effect appears to be stronger in dynamic shelf environments than offshore, where the strong stratification opposes mixing. The other paradigm considered is that the food web relies on a single burst of pelagic primary production during spring. Repeated instances of upwelling during summer provide food in a semi-continual fashion and, when combined with a longer icefree season, release herbivores from secular timing constraints. The third paradigm to revisit is that high-latitude pelagic systems are efficient vectors of vertical carbon export to the sea floor. On the contrary, IPY-CFL data confirmed that pelagic organisms strongly retain carbon in surface waters, as observed in other oligotrophic waters (e.g., tropical oceans).

While enhanced primary production resulting from upwelling or mixing in ice-free areas could result in increased fish and marine mammal harvest for Northerners, predictions from 
a global primary production-fisheries yield relationship suggest that current primary production levels would need to increase by two orders of magnitude to sustain a large-scale commercial fishery (Nixon and Thomas 2001). Such an increase presently appears unlikely in the High Arctic given the nutritive and energetic constraints imposed by the polar night and by nitrogen availability during the growth season.

Acknowledgments We thank the officers and crews of the CCGS Amundsen, Sir Wilfrid Laurier and Louis S. St-Laurent for their assistance at sea. We are grateful to the numerous colleagues and friends that contributed to the sampling and laboratory analyses or provided essential ancillary data. Jill Watkins and Scot Nickels, who have acted as editors for the collection of IPY papers, provided constructive comments that contributed much to the improvement of the manuscript. We gratefully acknowledge the support provided by the Canadian IPY office and particularly Tanuja Kulkarni (Aboriginal Affairs and Northern Development Canada). The CFL and C3O programs were funded by the Canadian International Polar Year (IPY) program office, the Natural Sciences and Engineering Research Council of Canada (NSERC), the Canada Research Chairs (CRC) Program and the Canada Foundation for Innovation (CFI). This work is a joint contribution to the Network of Centres of Excellence ArcticNet, Québec-Océan and ISMER.

Open Access This article is distributed under the terms of the Creative Commons Attribution License which permits any use, distribution, and reproduction in any medium, provided the original author(s) and the source are credited.

\section{References}

Ardyna M, Gosselin M, Michel C, Poulin M, Tremblay J-É (2011; in press) Environmental forcing of phytoplankton community structure and function in the Canadian High Arctic: contrasting oligotrophic and eutrophic regions. Mar Ecol Prog Ser

Arrigo KR, van Dijken G, Pabi S (2008) Impact of a shrinking Arctic ice cover on marine primary production. Geophys Res Lett 35:6

Ban A, Aikawa S, Hattori H, Sasaki H, Sampei M et al (2006) Comparative analysis of photosynthetic properties in ice algae and phytoplankton inhabiting Franklin Bay the Canadian Arctic, with those in mesophilic diatoms during CASES 03-04. Polar Biosci 19:11-28

Barber D, Massom R (2007) Chapter 1. The role of sea ice in Arctic and Antarctic polynyas. In: Smith W Jr, Barber D (eds) Elsevier oceanography Series 74. Elsevier, New York

Barber DG, Asplin MG, Gratton Y, Lukovich J, Galley RJ et al (2010) The International Polar Year (IPY) Circumpolar Flaw Lead (CFL) system study: overview and the physical system. Atmos-Ocean 48:225243

Ben Mustapha S, Larouche P, Dubois JMM (2010) Does AVHRR-Sea surface temperature fronts in the Beaufort Sea reveal biological hotspots? 2010 Ieee International Geoscience and Remote Sensing Symposium. New York, pp. 3696-3699

Brugel S (2009) Étude des variations spatiales et temporelles du phytoplancton en mer de Beaufort : biomasse, production et structure de taille des communautés. PhD thesis, Université du Québec à Rimouski

Buesseler KO (1998) The decoupling of production and particulate export in the surface ocean. Glob Biogeochem Cycle 12:297-310

Cai WJ, Chen LQ, Chen BS, Gao ZY, Lee SH et al (2010) Decrease in the $\mathrm{CO}_{2}$ uptake capacity in an ice-free Arctic Ocean basin. Science. doi:10.1126/science.1189338

Carmack EC (2007) The alpha/beta ocean distinction: a perspective on freshwater fluxes, convection, nutrients and productivity in high-latitude seas. Deep-Sea Res Part II-Top Stud Oceanogr 54:2578-2598

Carmack EC, McLaughlin FA (2011) Towards recognition of physical and geochemical change in Subarctic and Arctic Seas. Progr Oceanogr 90:90-104. doi:10.1016/j.pocean.2011.02.007

Carmack EC, McLaughlin FA, Vagle S, Melling H, Williams WJ (2010) Structures and property distributions in the three oceans surrounding Canada in 2007: a basis for a long-term ocean climate monitoring strategy. Atmos-Ocean 48:211-224

Chassot E, Bonhommeau S, Dulvy NK, Melin F, Watson R et al (2010) Global marine primary production constrains fisheries catches. Ecol Lett 13:495-505 
Chisholm SW (1992) Phytoplankton size. In: Falkowski PG, Woodhead AD (eds) Primary Productivity and Biogeochemical Cycles in the Sea. Plenum Press Div Plenum Publishing Corp, New York, pp. 213-237

Comeau A, Li WK, Tremblay J-É, Carmack EC, Lovejoy C (2011) Arctic Ocean Microbial Community Structure before and after the 2007 Record Sea Ice Minimum. PLoS One 6:e27492. doi:10.1371/ journal.pone.0027492

Conti L, Scardi M (2010) Fisheries yield and primary productivity in large marine ecosystems. Mar Ecol Prog Ser 410:233-244

Cushing DH (1989) A difference in structure between ecosystems in strongly stratified waters and in those that are only weakly stratified. J Plankton Res 11:1-13

Darnis G, Robert D, Pomerleau C, Link H, Archambault P, Nelson RJ, Geoffroy M, Tremblay J-É, Lovejoy C, Ferguson SH, Hunt BPV, Fortier L (2012) Current state and trends in Canadian Arctic marine ecosystems: II. Heterotrophic food web, pelagic-benthic coupling, and biodiversity. Clim Change. doi:10.1007/ s10584-012-0483-8

Dunbar M (1981) Physical causes and biological significance of polynyas and other open water in sea ice. In: Stirling I, Cleator H (eds) Polynyas in the Canadian Arctic, Canadian Wildlife Service, Ontario Occasional Paper Number 45. Ottawa, Canada, pp 29-43

Forest A, Tremblay J-É, Gratton Y, Martin J, Gagnon J et al (2011) Biogenic carbon flows through the planktonic food web of the Amundsen Gulf (Arctic Ocean): A synthesis of field measurements and inverse modeling analyses. Prog Oceanogr 91:410-436

Fortier M, Fortier L, Hattori H, Saito H, Legendre L (2001) Visual predators and the diel vertical migration of copepods under Arctic sea ice during the midnight sun. J Plankton Res 23:1263-1278

Gosselin M, Legendre L, Therriault J-C, Demers S, Rochet M (1986) Physical control of the horizontal patchiness of sea-ice microalgae. Mar Ecol Prog Ser 29:289-298

Gosselin M, Levasseur M, Wheeler PA, Horner RA, Booth BC (1997) New measurements of phytoplankton and ice algal production in the Arctic Ocean. Deep-Sea Res Part II-Top Stud Oceanogr 44:1623-1644

Gradinger R (2009) Sea-ice algae: major contributors to primary production and algal biomass in the Chukchi and Beaufort Seas during May/June 2002. Deep-Sea Res Part II-Top Stud Oceanogr 56:1201-1212

Gregor DJ, Loeng H, Len B (1998) The influence of physical and chemical processes on containment transport into and within the Arctic. AMAP Assessment Report: Arctic Pollution Issues. AMAP Secretariat, Oslo, pp 25-117

Hobson KA, Fisk A, Karnovsky N, Holst M, Gagnon J-M et al (2002) A stable isotopic $\left(\delta^{13} \mathrm{C}, \delta^{15} \mathrm{~N}\right)$ model for the North Water food web: implications for evaluating trophodynamics and the flow of energy and contaminants. Deep-Sea Res Part II-Top Stud Oceanogr 49:5131-5150

Horner R, Schrader GC (1982) Relative contributions of ice algae, phytoplankton, and benthic microalgae to primary production in nearshore regions of the Beaufort Sea. Arctic 35:485-503

Irigoien X, Huisman J, Harris RP (2004) Global biodiversity patterns of marine phytoplankton and zooplankton. Nature 429:863-867

Lee SH, Whitledge TE, Kang SH (2008) Spring time production of bottom ice algae in the landfast sea ice zone at Barrow, Alaska. J Exp Mar Biol Ecol 367:204-212

Li WKW, McLaughlin FA, Lovejoy C, Carmack EC (2009) Smallest algae thrive as the Arctic Ocean freshens. Science 326:539. doi:10.1126/science.1179798

Loeng H, Brander K, Carmack E, Denisenko N, Drinkwater K et al (eds) (2005) Arctic Climate Impact Assessment (ACIA). Cambridge University Press, Cambridge, pp 453-538

Lovejoy C, Vincent WF, Bonilla S, Roy S, Martineau MJ, Terrado R, Potvin M, Massana R, Pedros-Alio C (2007) Distribution, phylogeny, and growth of cold-adapted picoprasinophytes in arctic seas. J Phycol 43:78-89

Markus T, Stroeve JC, Miller J (2009) Recent changes in Arctic sea ice melt onset, freezeup, and melt season length. J Geophys Res-Oceans. doi:10.1029/2009JC005436

Martin J, Tremblay JE, Gagnon J, Tremblay G, Lapoussière A et al (2010) Prevalence, structure and properties of subsurface chlorophyll maxima in Canadian Arctic waters. Mar Ecol Prog Ser 412:69-84

Mathis JT, Pickart RS, Hansell DA, Kadko D, Bates NR (2007) Eddy transport of organic carbon and nutrients from the Chukchi Shelf: Impact on the upper halocline of the western Arctic Ocean. J Geophys Res: C05011

McLaughlin FA, Carmack EC (2010) Deepening of the nutricline and chlorophyll maximum in the Canada Basin interior, 2003-2009. Geophys Res Lett 37

Mundy CJ, Gosselin M, Ehn J, Gratton Y, Rossnagel A et al (2009) Contribution of under-ice primary production to an ice-edge upwelling phytoplankton bloom in the Canadian Beaufort Sea. Geophys Res Lett 36:L17601

Nixon S, Thomas A (2001) On the size of the Peru upwelling ecosystem. Deep-Sea Res Part I-Oceanogr Res Pap 48:2521-2528

Pabi S, van Dijken GL, Arrigo KR (2008) Primary production in the Arctic Ocean, 1998-2006. J Geophys Res-Oceans 113:22 
Popova EE, Yool A, Coward AC, Aksenov YK, Alderson SG, de Cuevas BA, Anderson TR (2010) Control of primary production in the Arctic by nutrients and light: insights from a high resolution ocean general circulation model. Biogeosciences Discuss 7:5557-5620

Proshutinsky A, Bourke R, McLaughlin F (2002) The role of the Beaufort Gyre in Arctic climate variability: Seasonal to decadal climate scales. Geophys Res Lett 29

Proshutinsky A, Krishfield R, Barber D (2009) Preface to special section on Beaufort Gyre Climate System Exploration Studies: Documenting key parameters to understand environmental variability. J Geophys Res 114:C00A08

Rainville L, Woodgate RA (2009) Observations of internal wave generation in the seasonally ice-free Arctic. Geophys Res Lett 36:L23604

Riedel A, Michel C, Gosselin M, LeBlanc B (2008) Winter-spring dynamics in sea-ice carbon cycling in the coastal Arctic Ocean. J Mar Sys 74:918-932

Rysgaard S, Nielsen TG, Hansen BW (1999) Seasonal variation in nutrients, pelagic primary production and grazing in a high-Arctic coastal marine ecosystem, Young Sound, northeast Greenland. Mar Ecol Prog Ser 179:13-25

Sakshaug E (2004) Primary and secondary production in the Arctic seas. In: Stein R, Macdonald RW (eds) The organic carbon cycle in the Arctic Ocean. Springer, Berlin, pp 57-81

Sarthou G, Timmermans KR, Blain S, Tréguer P (2005) Growth physiology and fate of diatoms in the ocean: a review. J Sea Res 53:25-42

Schoeman V, Becquevort S, Stefels J, Rousseau V, Lancelot C (2005) Phaeocystis blooms in the global ocean and their controlling mechanisms: a review. J Sea Res 53:43-66

Shadwick EH, Thomas H, Chierici M, Else B, Fransson A, Michel C, Miller LA, Mucci A, Niemi A, Papakyriakou TN, Tremblay JE (2011) Seasonal variability of the inorganic carbon system in the Amundsen Gulf region of the southeastern Beaufort Sea. Limnol Oceanogr 56:303-322

Smith M, Rigby B (1981) Distribution of polynyas in the Canadian Arctic. In: Stirling I, Cleator H (eds) Polynyas in the Canadian Arctic, Canadian Wildlife Service, Ontario Occasional Paper Number 45. Ottawa, Canada, pp 7-27

Søreide JE, Leu E, Graeve M, Falk-Petersen S (2010) Timing of blooms, algal food quality and Calanus glacialis reproduction and growth in a changing Arctic. Glob Change Biol 16:3154-3163

Stirling I (1997) The importance of polynyas, ice edges, and leads to marine mammals and birds. J Mar Sys 10:9-21

Terrado R, Medrinal E, Dasilva C, Thaler M, Vincent W, Lovejoy C (2011) Protist community composition during spring in an Arctic flaw lead polynya. Polar Biol 34:1901-1914

Tremblay J-E, Gagnon J (2009) The effects of irradiance and nutrient supply on the productivity of Arctic waters: a perspective on climate change. In: Nihoul JCJ, Kostianoy AG (eds) Influence of Climate Change on the Changing Arctic and Sub-Arctic Conditions. Elsevier, pp 73-93

Tremblay J-E, Smith Jr W (2007) Chapter 8. Primary production and nutrient dynamics in polynyas. in Smith W, Barber D (eds) Polynyas Windows to the world, Elsevier Oceanography Series, 74, Amsterdam, pp 239-269

Tremblay J-E, Lucas MI, Kattner G, Pollard R, Strass VH et al (2002) Significance of the polar frontal zone for large-sized diatoms and new production during summer in the Atlantic sector of the Southern Ocean. Deep-Sea Res Part II-Top Stud Oceanogr 49:3793-3812

Tremblay J-E, Hattori H, Michel C, Ringuette M, Mei ZP et al (2006a) Trophic structure and pathways of biogenic carbon flow in the eastern North Water Polynya. Prog Oceanogr 71:402-425

Tremblay J-E, Michel C, Hobson KA, Gosselin M, Price NM (2006b) Bloom dynamics in early opening waters of the Arctic Ocean. Limnol Oceanogr 51:900-912

Tremblay J-E, Simpson K, Martin J, Miller L, Gratton Y et al (2008) Vertical stability and the annual dynamics of nutrients and chlorophyll fluorescence in the coastal, southeast Beaufort Sea. J Geophys Res. doi:10.1029/2007JC004304

Tremblay J-E, Bélanger S, Barber DG, Asplin M, Martin J et al (2011) Climate forcing multiplies biological productivity in the coastal Arctic Ocean. Geophys Res Lett 38:L18604

Tynan CT, DeMaster DP (1997) Observations and predictions of Arctic climatic change: potential effects on marine mammals. Arctic 50:308-322

Vaquer-Sunyer R, Duarte CM, Santiago R, Wassmann P, Reigstad M (2010) Experimental evaluation of planktonic respiration response to warming in the European Arctic Sector. Polar Biol 33:16611671

Ware DM, Thomson RE (2005) Bottom-up ecosystem trophic dynamics determine fish production in the northeast Pacific. Science 308:1280-1284

Wassmann P (1998) Retention versus export food chains: processes controlling sinking loss from marine pelagic systems. Hydrobiologia 363:29-57 
Wassmann P, Andreassen IJ, Rey F (1999) Seasonal variation of nutrients and suspended biomass on a transect across Nordvestbanken, north Norwegian shelf, in 1994. Sarsia 84:3-4

Williams WJ, Carmack EC (2008) Combined effect of wind-forcing and isobath divergence on upwelling at Cape Bathurst, Beaufort Sea. J Mar Res 66:645-663

Williams W, Carmack E, Ingram R (2007) Chapter 2. Physical oceanography of polynyas. In: Smith W, Barber D (eds) Polynyas Windows to the world Elsevier Oceanography Series, 74, Amsterdam, pp 55-85

Yamamoto-Kawai M, McLaughlin FA, Carmack EC, Nishino S, Shimada K (2008) Freshwater budget of the Canada Basin, Arctic Ocean, from salinity, 818O, and nutrients. J Geophys Res 113:C01007. doi:10.1029/2006JC003858

Yang JY (2009) Seasonal and interannual variability of downwelling in the Beaufort Sea. J Geophys ResOceans. doi:10.1029/2008JC005084

Zhang X, Walsh JE, Zhang J, Bhatt US, Ikeda M (2004) Interannual variability of Arctic cyclone activity, 1948-2002. J Clim 17:2300-2317 